\title{
The effect of eco-friendly practices on green image and customer attitudes
}

\author{
Christina Rahardja Honantha, Dudi Anandya, \& Andhy Setyawan \\ University of Surabaya, Surabaya, Indonesia
}

\begin{abstract}
This study aims to examine the relationship between customers' perceived green practices, perceived green image, and attitudes of a canteen, as well as identify the key green practices that influence customers' perceptions of a canteen's green image. The model used for this study was adopted from Namkung \& Jang (2013). The respondents were 200 people consisting of university employees, lecturers, and students. Data were analyzed using Structural Equation Model (SEM). The results suggested that the perception of green practices affects customers' perceived green image of a canteen which in turn influences customers' attitudes towards a canteen. Secondly, the study identified recyclable take-out containers, recycling waste, and energy-efficient lighting as the key green practices that contribute to the formation of customers' perceptions of a canteen's green image. Finally, the paper includes a theoretical model and offers practical guidelines for effective green marketing management in Keluwih canteen management.
\end{abstract}

Keywords: green practices, perceived green image, consumer attitude

\section{INTRODUCTION}

Nowadays the phenomenon shows that companies which implement the environmentally friendly principle have better business continuity (Earthshare 2012). As an institution which is responsible for education in the future, a university is responsible for teaching the environmentally friendly lifestyle. Eco campus is a campus as part of city ecosystem and it should have an environment that is comfortable, clean and also support the environmental preservation in the neighborhood (Nasoetion 2009). In the context of eco-campus, the canteen is one of the locations which should be concerned in order to enable making an environmentally friendly canteen that provides healthy meals. Paying high attention on the ecocampus, the University of Surabaya (UBAYA) as one of the leading universities in Indonesia established an environmentally friendly canteen namely Keluwih canteen. The canteen began to apply the green canteen concept in 2004. The concept is applied in a simple way by sorting out food waste into three different recycling bins of a blue bin for plastic waste, a yellow bin for paper waste, and a green bin for leftover foods. Tables and walls of the canteen were also designed with codes to introduce healthy and environmentally friendly lifestyle. The capacity of the canteen is 184 chairs for the ground floor while the upper ground floor has almost the same numbers of chairs but with different design and layout.

Keluwih canteen is situated in two different locations. The first one is nearby the Faculty of Business and Economics, while the second one is on the first floor of Faculty of Medicine. The second Keluwih canteen was opened and started to operate in 2016.

In making a decision where to eat, consumers really consider the restaurant image and choose restaurants which have a positive image (Namkung \& Jang 2013). The previous research showed that the environmentally friendly practice in a restaurant (green restaurant) affects brand equity (Namkung \& Jang 2013), however, the research about the impact of environmentally friendly activities on the consumers' choice is still few (Namkung \& Jang 2013). 
The research problem; Do the perception of the green practice and the green image of Keluwih canteen influence the behavior of consumers towards Keluwih canteen in UBAYA?

The environmentally friendly practices have been long considered as an important component of company reputation and the core elements of company image (Miles \& Covin 2000, Schwaiger 2004). The environmentally friendly image can be expressed as a prominent point of environmentally friendly attributes of a certain restaurant. Customer perception of the environmentally friendly image of a restaurant can be measured from the environmentally friendly practices which are important for the evaluation of greenness restaurant (Bloemer \& de Ruyter 1998). According to Ajzen \& Fishbein (2000), customer behavior is determined by the value and faith which is subjective related to the restaurants.

Chen (2008) showed the positive relationship between green practices and green images. Namkung \& Jang (2013) proved that restaurants' green practices positively influence the brand image of environmentally friendly restaurants and the behavioral intention of environmentally friendly customers.

Chen (2010), Jeong et al. (2014) stated that customers who recognize the serious needs of ecological problems tend to appreciate restaurant's efforts to implement eco-friendly practices which will form customers' strong perception on greenness restaurant.

On the other hand, this matter directly produces a positive impression on the entire restaurant and helps customers to form positive behavior towards the restaurant.

The purpose of this research is to examine the relationship between customers' perceived green practices, perceived green image of a canteen, and attitudes of Keluwih canteen customers and identify the key green practices that influence customers' perceptions of a canteen's green image.

These are three hypotheses to test:

H1. The customers' perception of the green practice has a significant positive impact on perception towards the green image of Keluwih canteen in UBAYA.

$\mathrm{H} 2$. The customers' perception of the green practice has a significant positive influence towards the behavior of consumers of Keluwih canteen in UBAYA.
H3. The customers' perception of the green image has a significant positive influence on the behavior towards Keluwih canteen in UBAYA.

\section{RESEARCH METHODS}

This research used a quantitative approach with confirmation, including an observation on social reality, building hypotheses based on available theories, and collecting accurate data to test hypotheses. The result of hypothesis testing led to confirmation or development of the theory in the future (Saunders et al. 2009, Neuman 2011). There are 4 variables: perception variable of the green practice (PPRL) that serves as free variable; perception variable of the green image (PCRL) that serves as media variable; perception variable of the effectiveness of the green behavior (PKRL) that serves as moderation variable, and consumer behavior variable (SK) that serves as bound variable. According to Cozby \& Bates (2012), purposive sampling is one of the forms in non-probability sampling which aims to gain samples or respondents from individuals who are suitable with the criteria set by the authors.

The authors also specified the characteristics of respondents were the consumers of Keluwih canteen for the last 6 months; regularly buy meals in Keluwih canteen UBAYA in the last one month; have a minimum educational background of high school, and reside in Surabaya. The samples were 200 respondents.

The data analysis was conducted by using Structural Equation Modeling (SEM) with AMOS. The estimation used Maximum Likelihood (ML).

\section{RESULTS AND DISCUSSIONS}

The spreading of data respondents are based on gender. Female respondents are $56.6 \%$ and male respondents are $43.5 \%$.

The analysis of measurement model is conducted by using Confirmatory Factor Analysis (CFA), the early stage of CFA has the value of Goodness-OfFit (GOF) which fulfill the suitable criteria $\left(\chi^{2} / \mathrm{df}=\right.$ 1.586 , RMSEA $=0.054$, GFI $=0.898$, TLI $=0.941$, and $\mathrm{CFI}=0.950$ ).

The result of structural model without moderation is shown in figure 1. 


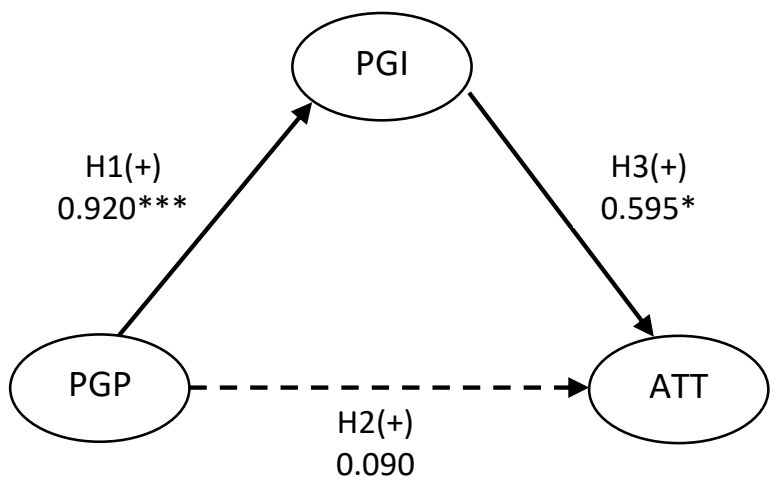

Figure 1. Structural Model

${ }^{a}$ The value of standardized estimate. The insignificant structural relationship is described by dotted lines.

$$
\begin{aligned}
* p & \leq 0.1 \\
* * p & \leq 0.05 \\
* * * p & \leq 0.001
\end{aligned}
$$

Out of three hypotheses tested using structural model, only the second hypothesis is not supported. It indicates that there is a positive influence of PGP on behavior through media variable PGI. The positive influence of PGP on ATT is directly

\begin{tabular}{|c|c|c|c|c|}
\hline $\begin{array}{l}\text { The } \\
\text { relationship } \\
\text { of } \\
\text { Structural } \\
\text { construct }\end{array}$ & $\begin{array}{c}\text { Standardized } \\
\text { Estimation } \\
\text { Value }\end{array}$ & $\begin{array}{c}\text { Critical } \\
\text { Ratio }\end{array}$ & $\begin{array}{c}P- \\
\text { value }\end{array}$ & Information \\
\hline PGP $\rightarrow$ PGI & 0.920 & 6.958 & $* * *$ & $\begin{array}{c}\text { H1 } \\
\text { supported }\end{array}$ \\
\hline $\mathrm{PGP} \rightarrow \mathrm{ATT}$ & 0.090 & 0.278 & 0.781 & $\begin{array}{c}\mathrm{H} 2 \\
\text { unsupported }\end{array}$ \\
\hline PGI $\rightarrow$ ATT & 0.595 & 1.852 & 0.064 & $\begin{array}{c}\text { H3 } \\
\text { supported }\end{array}$ \\
\hline
\end{tabular}
unsupported by empirical data.

Table 1. Hypotheses test

**** coefficient is significant on $P$-value $<0.001$

In line with the research of Jeong et al. (2014), the green practices do not influence the behavior (ATT) towards Keluwih canteen. The green image of Keluwih canteen is media variable between green practices and the consumer behavior of the canteen. Therefore, promotion effort or advertisement by Keluwih canteen is needed, so there will be more positive consumer behavior towards green practices in Keluwih canteen.

\section{CONCLUSIONS}

The conclusions of this research are: (1). The customers' perception of the green practices has a significant positive influence on image perception of Keluwih canteen, (2). The customers' perception of the green practices has no significant positive influence on consumers' behavior of Keluwih canteen, and (3). The customers' perception of the green image has a significant positive influence on the behavior towards Keluwih canteen in UBAYA.

The research implication is that green practices implemented by Keluwih canteen management UBAYA (ATT) should be more consistent and sincere. The three different recycling bins to sort out food waste; the practice of using the environmentally friendly material for packaging, and the energy-saving practice using the LED lamp or solar energy should be consistently applied by the Keluwih canteen with more consistent food waste management. When collecting the food waste to the final disposal, it should be kept separate where plastic and paper waste can be recycled and the leftover food waste can be reused for compost and another usage.

Further research is needed to find out generalizations of this research model, especially with the eating venue set in a public area and more diverse respondents. Keluwih canteen was established with the green concept and considering its location on the campus, the customers are mostly students and lecturers. In this condition, the level of educational background and age range are homogeneous. This research model should be tested in a broader context with more diverse respondents.

For further research, it is planned to be done in a broader scope until the national level. Moreover, it is necessary to include purchase intention considering intention is a behavioral predictor. This study only stops to the attitude variable, so it needs to be further studied to the purchasing intention variable as studied by Ajzen \& Fishbein (2000) and Kwun (2011).

\section{REFERENCES}

Ajzen, I. \& Fishbein, M. 2000. Attitudes and the attitudebehavior relation: reasoned and automatic processes. Eur. Rev. Soc. Psychol 11(1): 1-33.

Bloemer, J. \& de Ruyter, K. 1998. On the relationship between store image, store satisfaction and store loyalty. Eur. J. Market 32 (5/6): 499-513.

Chen, Y.S. 2008. The driver of green innovation and green image-green core competence. Journal of Business Ethics 81(3): 531-543.

Chen, Y.S. 2010. The drivers of green brand equity: green brand image, green satisfaction, and green trust. Journal of Business Ethics 93(2): 307-319. 
Cozby, P.C. \& Bates, S. 2012. Methods in Behavioral Research. New York: McGraw-Hill.

Earthshare. 2012. Green Tips: Sustainable Investing. Retrieved from http://www.earthshare.org/2012/03/green-tipssustainable-investing.html.

Jeong, E.H., Jang, S.C., Day, J. \& Ha, S. 2014. The impact of eco-friendly practices on green image and customer attitudes: An investigation in a café setting, International Journal of Hospitality Management 41: 10-20.

Kwun, D.J.W. 2011. Effects of campus foodservice attributes on perceived value, satisfaction, and consumer attitude: a gender-difference approach. Int. J. Hospital.Management 30(2): 252-261.

Miles, M. \& Covin, J. 2000. Environmental Marketing: A Source of Reputational, Competitive, and Financial Advantage. Journal of Business Ethics 23(3): 299-311.

Namkung, Y. \& Jang, S. 2013. Effects of restaurant green practices on brand equity formation: Do green practices really matter? Int. J. Hospital. Management 33: 85-95.

Nasoetion, P. 2009. Green Campus vs Pemanasan Global. Retrieved from http://gogreenindonesiaku.blogdetik.com /2009/12/07/green-campus-vs-pemanasan-global.

Neuman, W.L. 2011. Social Research Methods: Qualitative and Quantitative Approaches. 7th Edition. Edinburgh Gate Harlow Essex: Prentice Hall.

Saunders, M., Lewis, P. \& Thornhill, A. 2009. Research Methods for Business Students. $5^{\text {th }}$ ed. Edinburgh Gate Harlow Essex: Prentice Hall.

Schwaiger, M. 2004. Components and Parameters of Corporate Reputation - an Empirical Study. Schmalenbach Business Review 56(1): 46-71. 